[Original]

\title{
Activity Related to the Carcinogenicity of Plastic Additives in the Benzophenone Group
}

\author{
Daisuke NAKAJIMA', Shin ASADA², Shiho KAGEYAMA', Takashi YAMAMOTO, \\ Hidetoshi KuRAmOCHI ${ }^{3}$, Noriho TANAKA ${ }^{2}$, Ken TAKEDA ${ }^{4}$ and Sumio GoTO ${ }^{1}$ \\ ${ }^{1}$ Research Center for Environmental Risk, National Institute for Environmental Studies, Onogawa, Tsukuba, \\ Ibaraki 305-8506, Japan \\ ${ }^{2}$ Department of Cell Biology, Hatano Research Institute, Food and Drug Safety Center, Ochiai, Hadano, \\ Kanagawa 257-8523, Japan \\ ${ }^{3}$ Research Center for Material Cycles and Waste Management, National Institute for Environmental Studies, \\ Onogawa, Tsukuba, Ibaraki 305-8506, Japan \\ ${ }^{4}$ Faculty of Pharmaceutical Sciences, Tokyo University of Science, Yamazaki, Noda, Chiba 289-8510, \\ Japan
}

Abstract: This study examines the activities relating to the carcinogenicity of six types of benzophenone derivatives (benzophenone, 2-hydroxy-4-octyloxybenzophenone, 2hydroxy-4-methoxybenzophenone, 2,4-dihydroxybenzophenone, 2,2'-dihydroxy4-methoxybenzophenone and 2,2'-dihydroxy-4,4'-dimethoxybenzophenone) currently used in plastic products as additives to serve as ultraviolet absorbing agents. The evaluation of the initiation activity used a light absorption $u m u$-test, a luminescent $и m u$-test and the Ames test. The promotion activity was examined by a Bhas assay, a method that uses Bhas 42 cells for the formation of transformation foci. The luminescent $u m u$-test indicated positive initiation activity of 2-hydroxy-4-methoxybenzophenone, and pseudo-positive activity of 2,4-dihydroxybenzophenone and 2,2'-dihydroxy-4-methoxybenzophenone. In the Ames test, 2-hydroxy-4-octyloxybenzophenone showed pseudo-positive initiation activity. Conversely, 2,4-dihydroxybenzophenone indicated weak promotion activity at $10 \mu \mathrm{g} / \mathrm{ml}$ concentration.

Key words: luminescent $u m u$-test, light absorption $u m u$-test, Ames test, Bhas promotion assay, 2,4-dihydroxybenzophenone.

(Received 31 October 2005, accepted 8 March 2006)

\section{Introduction}

Plastic products are a common sight in every aspect of our living environment today. They contain a wide variety of additives, including plasticizers, fire retardants, antioxidants and ultraviolet absorbing agents. Benzophenone and its derivatives are typical ultraviolet 
absorbing agents. Japan consumed approximately $550 \mathrm{t}$ in 1995 [1]. Because cosmetics and soaps also use benzophenones (BPs) for aroma retention [2], it is possible that we are exposed to them on a daily basis for a long time. Furthermore, plastic products are often treated in intermediate processes, such as crushing, during their recycling or before their final disposal. As they are subjected to high heat and pressure at some point during these processes, the additives contained in them may vaporize or drift into the air. The released plastic additives may contaminate the atmosphere, resulting in a further possibility of our direct or indirect exposure to them. Long-term exposure to chemicals may have many implications for our health, including sensitization, endocrine disruption and carcinogenesis. Strategic Program on Environmental Endocrive Disrupters (SPEED) '98 lists benzophenone as potential endocrine disrupters [3], and many studies have investigated them to determine their effects and abundance in the environment [4-6]. There are, however, very few reports on the activity of BPs relating to carcinogenesis $[7,8]$.

The multistep theory [9] has been widely accepted as the explanation of the mechanism of carcinogenesis. According to this theory, there are at least two processes in carcinogenesis. The first step is the initiation process that begins with genetic damage or mutation caused by chemical substances. The second step is the promotion process in which exposure to certain chemicals or other mechanisms leads the initiated genes to carcinogenesis. Typical methods for testing initiation activity include the $u m u$-test [10-12], which detects genetic damage using the expression of the genes involved in SOS repair that follows the damage, and the Ames test $[13,14]$, which detects mutation triggered by genetic damage. Although the promotion assays took place mainly in vivo in the past, the development of simple and quick in vitro methods has made progress [15-17]. Specifically, the Bhas assay is a test to detect the formation of transformation foci using initiated Bhas 42 cells established from BALB/3T3 cells. This is the fastest method at present and produces results in about 3 weeks [18]. In addition to its use in evaluating chemicals such as termiticides [19], it is already used in the evaluation of airborne particulate and other environmental samples [20].

It has been reported that benzophenone has neither mutagenicity nor carcinogenicity. On the other hand, there are different results about benzophenone derivatives [7, 21, 22]. For example, some derivatives, such as 2,2'-dihydroxy-4-methoxybenzophenone, 2,2'dihydroxy-4,4'-dimethoxybenzophenone and 2,2',4,4'-tetrahydroxybenzophenone, showed the mutagenicity when they were metabolically activated with microsomal fractions of hamster [7, 23-25]. It was also reported that one of the derivatives, 2-hydroxy-4methoxybenzophenone, does not have mutagenicity [7]. However, the possibility of DNA damaging activity (SOS-inducing activity) of these derivatives has not been examined. About a possible role of a cancer promoting activity of derivatives, it has been only reported that 4,4'-dihydroxybenzophenone played as a cancer promoter [26] so far.

Our study investigated the carcinogenic initiation and promotion activities of six types of 
Table 1. Chemical structure of benzophenone and its derivatives tested in this work

\begin{tabular}{lrrrrr}
\hline \multirow{2}{*}{$\begin{array}{l}\text { Chemicals } \\
\text { tested }\end{array}$} & M.W. & \multicolumn{5}{c}{ Substituents** } \\
\cline { 3 - 6 } & & 2 & 2 & 4 & 4 \\
\hline BP & 182 & $\mathrm{H}$ & $\mathrm{H}$ & $\mathrm{H}$ & $\mathrm{H}$ \\
HOBP & 326 & $\mathrm{OH}$ & $\mathrm{H}$ & $\mathrm{OC}_{8} \mathrm{H}_{17}$ & $\mathrm{H}$ \\
HMBP & 228 & $\mathrm{OH}$ & $\mathrm{H}$ & $\mathrm{OCH}_{3}$ & $\mathrm{H}$ \\
DHBP & 214 & $\mathrm{OH}$ & $\mathrm{H}$ & $\mathrm{OH}$ & $\mathrm{H}$ \\
DHMBP & 244 & $\mathrm{OH}$ & $\mathrm{OH}$ & $\mathrm{OCH}_{3}$ & $\mathrm{H}$ \\
DHDMBP & 274 & $\mathrm{OH}$ & $\mathrm{OH}$ & $\mathrm{OCH}_{3}$ & $\mathrm{OCH}_{3}$ \\
\hline
\end{tabular}

*: BP: benzophenone, HOBP: 2-hydroxy-4-octyloxybenzophenone, HMBP: 2-hydroxy-4-methoxybenzophenone, DHBP: 2,4-dihydroxybenzophenone, DHMBP: 2,2'-dihydroxy-4-methoxybenzophenone, DHDMBP: 2,2'dihydroxy-4,4'-dimethoxybenzophenone

**: Structure and numbering scheme of benzophenone:<smiles>O=C(c1ccccc1)c1ccccc1</smiles>

BPs used as ultraviolet absorbing agents. This report describes the results of the tests we conducted in our study, specifically, the luminescent and light absorption $u m u$-tests for genetic damage, which is one of the initiation activities, the Ames pre-incubation test for mutagenicity, and the Bhas assay, which is the transformation foci method using Bhas 42 cells established from BALB/3T3, for assessing promotion activity.

\section{Experiments}

\section{Reagents}

The tests used the purest forms of benzophenone (BP), 2-hydroxy-4-octyloxybenzophenone (HOBP), 2-hydroxy-4-methoxybenzophenone (HMBP), 2,4-dihydroxybenzophenone (DHBP), 2,2'-dihydroxy-4-methoxybenzophenone (DHMBP) and 2,2'-dihydroxy-4,4'-dimethoxybenzophenone (DHDMBP) manufactured by Wako Pure Chemical Industries (Osaka, Japan). The chemical structures of these benzophenones are shown in Table 1.

\section{Luminescent umu-test}

The luminescent $u m u$-test was performed using the Salmonella (S.) typhimurium TL210 strain by the method used in a previous report by Nakajima et al. [27], with some modifications. Specifically, a quickly-thawed frozen culture of $1.25 \times 10^{7}$ cells was seeded in $24 \mathrm{ml}$ of TGA medium ( $1 \%$ bacto-tryptone, $0.5 \% \mathrm{NaCl}, 0.2 \%$ glucose and $20 \mu \mathrm{g} / \mathrm{ml}$ ampicillin) 
in an Erlenmeyer flask, and shake-cultured $(120 \mathrm{rpm})$ in an incubator at $37^{\circ} \mathrm{C}$ for $2 \mathrm{~h}$. The light absorbance $(600 \mathrm{~nm})$ of the incubated bacterial culture was measured (normally approx. 0.2 ). The culture was then diluted with TGA medium to adjust the absorbance to 0.1. A 4$\mu l$ quantity of test substance, which was serially diluted with DMSO and methanol, was placed in a 96 well clear-bottomed black plate (Matrix Technologies, Hudson, NH), to which was added $200 \mu \mathrm{l}$ per well of the prepared bacterial suspension, and mixed well with a mixer. The plate was allowed to stand in an incubator at $30^{\circ} \mathrm{C}$. The luminescence was measured at $20 \mathrm{~min}$ intervals over a period between 120 and $240 \mathrm{~min}$ after the onset of response. The measurements of luminescence and turbidity were carried out with a JNR AB2100 luminescence reader (ATTO, Tokyo, Japan) and a Wallac 1420 ARVOsx multi-label counter (Perkin Elmer Inc., Wellesley, MA), respectively. The luminescence was measured as the integrated value at $1 \mathrm{~s}$ per well. The luminescence values measured at the time when the solvent controls produced the highest luminescence (normally after 180 to $220 \mathrm{~min}$ ) were used for evaluation. This is a simplified method that does not require a matrix. Instead, it uses the S. typhimurium TL210 strain, which is based on the Salmonella bacteria TA1535/ pSK1002 strain used in the conventional $u m u$-test (i.e. light absorption). The TA1535/pSK 1002 strain has its pSK1002 plasmid (drug-resistant factor) genetically modified with luminescent gene group luxA-E derived from bioluminescent bacteria $V$. fischeri [12].

\section{Light absorption umu-test}

The light absorption umu-test used the $S$. typhimurium TA1535/pSK1002 strain, with chlorophenolred- $\beta$-D-galactopyranoside (CPRG) as the substrate [27]. Specifically, a quickly-thawed frozen culture was seeded onto an LB medium ( $0.1 \%$ bacto-tryptone, $0.5 \%$ yeast extract, $0.5 \% \mathrm{NaCl}$, adjusted $\mathrm{pH}$ at 7.0 using $1 \mathrm{M} \mathrm{NaOH}$ ), and incubated at $37^{\circ} \mathrm{C}$ for $12 \mathrm{~h}$, and shaken at $120 \mathrm{rpm}$. This liquid culture was diluted 100 times with TGA medium, and shake-cultured for another $2 \mathrm{~h}$. The resultant liquid culture and test substances were placed onto a microplate, sealed, and mixed well with the plate mixer. The mixture was then shake-cultured at $900 \mathrm{rpm}$ at $37^{\circ} \mathrm{C}$ for $4 \mathrm{~h}$, after which the viable cell count in the bacterial suspension was estimated by $\mathrm{OD}_{595}$. A $10 \mu \mathrm{l}$ quantity of the bacterial suspension was transferred to another 96 well microplate, and diluted with $140 \mu \mathrm{l}$ of $\mathrm{Z}$ buffer $(60 \mathrm{mM}$ $\mathrm{Na}_{2} \mathrm{HPO}_{4}, 40 \mathrm{mM} \mathrm{NaH} \mathrm{PO}_{4}, 10 \mathrm{mM} \mathrm{KCl}, 1 \mathrm{mM} \mathrm{MgSO}, 1 \% \mathrm{SDS}$ and $50 \mathrm{mM} 2-$ mercaptoethanol). A $10 \mu \mathrm{l}$ quantity $(4 \mathrm{mg} / \mathrm{ml})$ of CPRG was added to this solution. The solution was cultured at $37^{\circ} \mathrm{C}$ for $30 \mathrm{~min}$, and $100 \mu \mathrm{l}$ of $1 \mathrm{M} \mathrm{Na}_{2} \mathrm{CO}_{3}$ was added to stop coloration. Afterwards, the $\beta$-galactosidase activity ( $u m u$ unit $=\mathrm{OD}_{570} / \mathrm{OD}_{595}$ ) was measured by $\mathrm{OD}_{570}$.

\section{Ames test}

The Ames test used S. typhimurium TA 98 and TA 100 strains [7]. A DMSO solution of the test substances and the bacterial suspension were placed in sterilized test tubes with 
aluminum caps. $S 9$ mix was added for the with $S 9$ condition $(+S 9)$, and for the without $S 9$ condition ( $-\mathrm{S} 9) 0.1 \mathrm{M}$ of sodium phosphate buffer was added. After 20 min preincubation at $37^{\circ} \mathrm{C}$, soft agar was added and mixed. The mixture was spread over the plate. After incubation at $37^{\circ} \mathrm{C}$ for $48 \mathrm{~h}$, the number of revertant colonies was counted. The S9 mix was prepared from a frozen product containing a set of cofactors and S9 solution (S9/ Cofactor A set for the Ames test; Oriental Yeast Co., Yokohama, Japan). The sample solutions, including the solvent control, were diluted with DMSO to doses of seven different strengths. The test was performed with two plates for each dose. As positive controls, benzo[a]pyrene (BaP) was used for the + S9 condition, and 2-(2-furyl)-3-(5-nitro-2-furyl) acrylamide (AF2) for the $-\mathrm{S} 9$ condition. Mutagenicity was determined to be "pseudopositive" for those with good dose-response and with from 1.5 to 2 times as many revertant colonies as spontaneous revertant colonies; mutagenicity was determined to be "positive" for those with more than 2 times as many revertant colonies as spontaneous revertant colonies. In addition, the plate surface was examined under a microscope for the presence of inhibited bacterial growth.

\section{Promotion test}

Bhas promotion assay was conducted according to the procedure reported by Ohmori et al. [18] and Goto et al. [19], as described below. Subconfluent Bhas42 cells were peeled off from the culture dish using trypsin, and prepared as samples of $2 \times 10^{4}$ cells $/ \mathrm{ml}$. The cell suspension was divided between a 6 cell microplate at $2 \mathrm{ml} /$ well for the promotion test and a 24 well microplate at $0.5 \mathrm{ml} /$ well for the cytotoxicity test, and incubated for 3 days. On the third day of incubation, the medium was removed, and replaced by the medium containing the test substances. Based on the result of the dosage test, six doses consisting of 2, $5,10,20,50$ and $100 \mu \mathrm{g} / \mathrm{ml}$ were used for the tests. In the cytotoxicity test, the cells were fixed with formalin on the seventh day of incubation, dyed with $0.1 \%$ crystal violet, and washed with water. The washed cells were dried, and extracted using a color extraction solution containing $0.1 \mathrm{M} \mathrm{HCl}$ and $50 \%$ ethanol. The light absorbance at $540 \mathrm{~nm}$ was measured using Sunrise Classic (Wako Pure Chemical Ind.) for the calculation of survival rates. In the promotion test, the medium was replaced on the seventh and tenth days of incubation with another containing the test substance. On the 14th day of incubation, the medium was replaced with another containing no test substance. On the 21 st day, the cells were fixed with methanol, and dyed with 5\% Giemsa solution. After air-drying, the number of transformation foci were counted under a stereoscopic microscope. The transformation foci were identified on the basis of five criteria: 1 . more than 50 cells in a focus area, 2. cells in the focus area are spindle-shaped and different from surrounding cells, 3 . cells in the focus area cross each other in a random sequence, 4 . cells grow in a stacked manner, and 5. the cytoplasm is intensely dyed by basicity. 12-O-tetra-decanoyl-phorbol-13-acetate (TPA; Wako Pure Chemicals Ind.) was used as a positive control. 


\section{Statistial analysis}

The obtained results data were assessed by 1-way analysis of variance (ANOVA) with $p$ $<0.05$ significance level. In cases where a difference was found, student-Newman-keuls test was carried out as a post hoc test.

\section{Results and Discussion}

\section{The umu-tests for initiation activity}

First, the genotoxicity of the benzophenones was examined using the umu-test. The original method of the $u m u$-test (the conventional method) [10] uses bacteria which had a $\beta$ galactosidase gene added downstream of the umu operon, to which galactoside was added as the substrate. Truncated aglycons are detected by light absorbance. Several alternative methods have been developed, including a fluorescent $u m u$-test which is designed to detect fluorescent aglycons [11], and a luminescent $u m u$-test which uses the luciferase gene in place of the original $\beta$-galactosidase gene [12]. In the bioassay of chemical substances, a general practice is to use DMSO as the solvent when the samples are not water-soluble. DMSO, however, is known to induce some SOS response [28]. As a result, it may produce relatively high values as a solvent control in the luminescent $u m u$-test, which has a higher sensitivity than its light absorption method. For this reason, methanol is effective for the measurement of substances with weaker activity, because it has less luminescence when used as a solvent control [21]. This study used both DMSO and methanol as dilution solvents and tested measurements taken from both solvents (Fig. 1). In all samples, the value of the solvent control was smaller for the dilution with methanol than that with DMSO. From among the six types of compounds tested, HMBP in particular gave twice as much luminescence as its solvent control, resulting in a positive conclusion (with methanol as the solvent). DHBP and DHMBP showed increases in luminescence corresponding to dosage, as well as a rapid decrease at higher concentrations. The $\mathrm{OD}_{595}$ values for both of these compounds were less than half of the values for their respective solvent controls at concentrations of $10 \mu \mathrm{g} /$ well, suggesting an effect from the inhibition of bacterial growth.

The light absorption $u m u$-test also used both DMSO and methanol as solvents for dilution (Fig. 2). None of the compounds, including HMBP which was positive in the luminescent $u m u$-test, showed clear positive results in this concentration range. However, DHBP, which showed a pseudo-positive response in the luminescent $u m u$-test, produced small dosedependent increases in $и т и$ activity when methanol was used as the solvent. Since the sensitivity is generally considered higher in the luminescent $u m u$-test than the light absorption version [12], the difference in sensitivity is believed to be the reason why the compounds that showed positive or pseudo-positive responses in the above luminescent umu-test produced negative results in the light absorption test. 

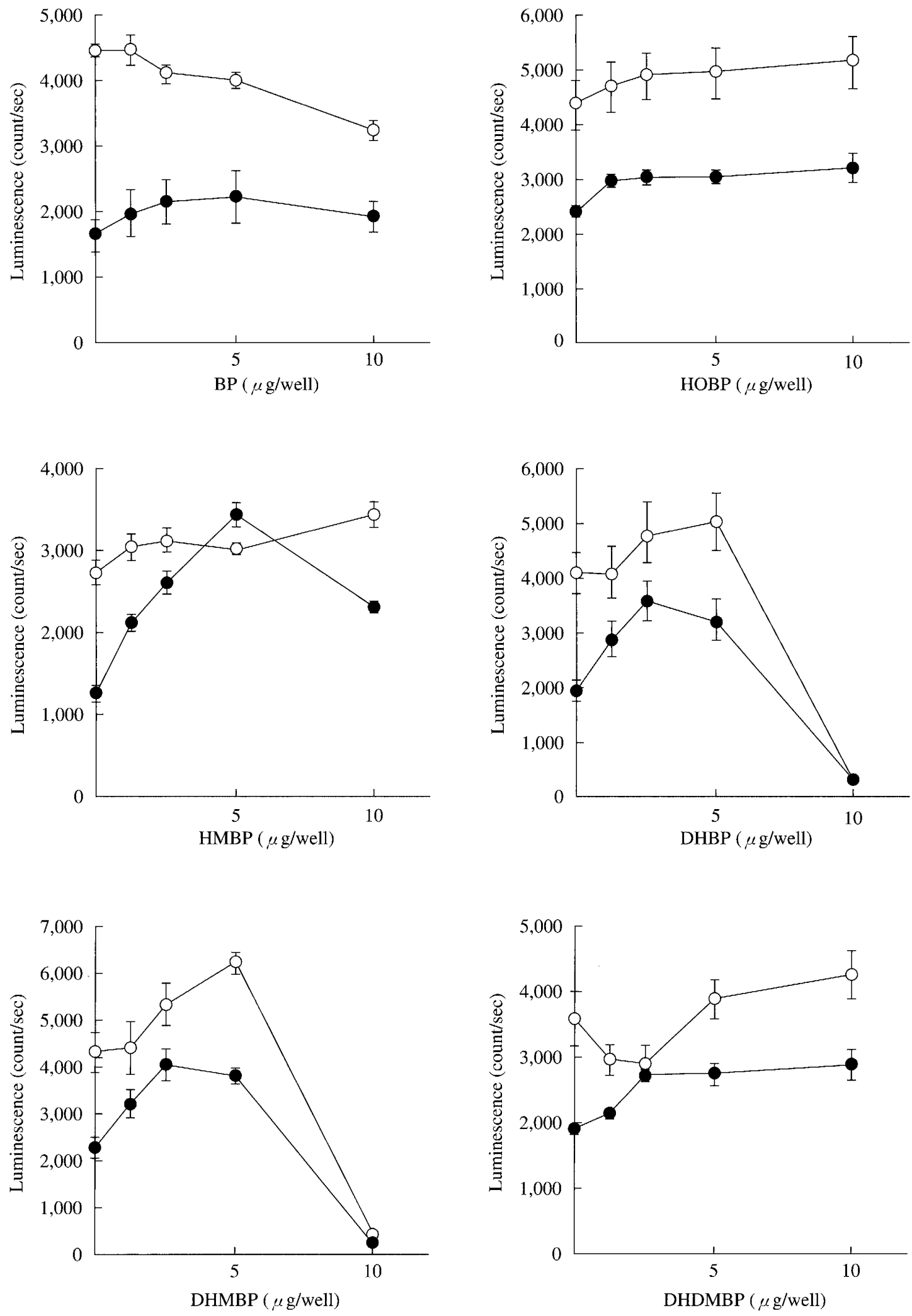

Fig. 1. Results of the luminescent umu-test of benzophenones.

$\bigcirc$ : Diluted with DMSO, : Diluted with methanol. 

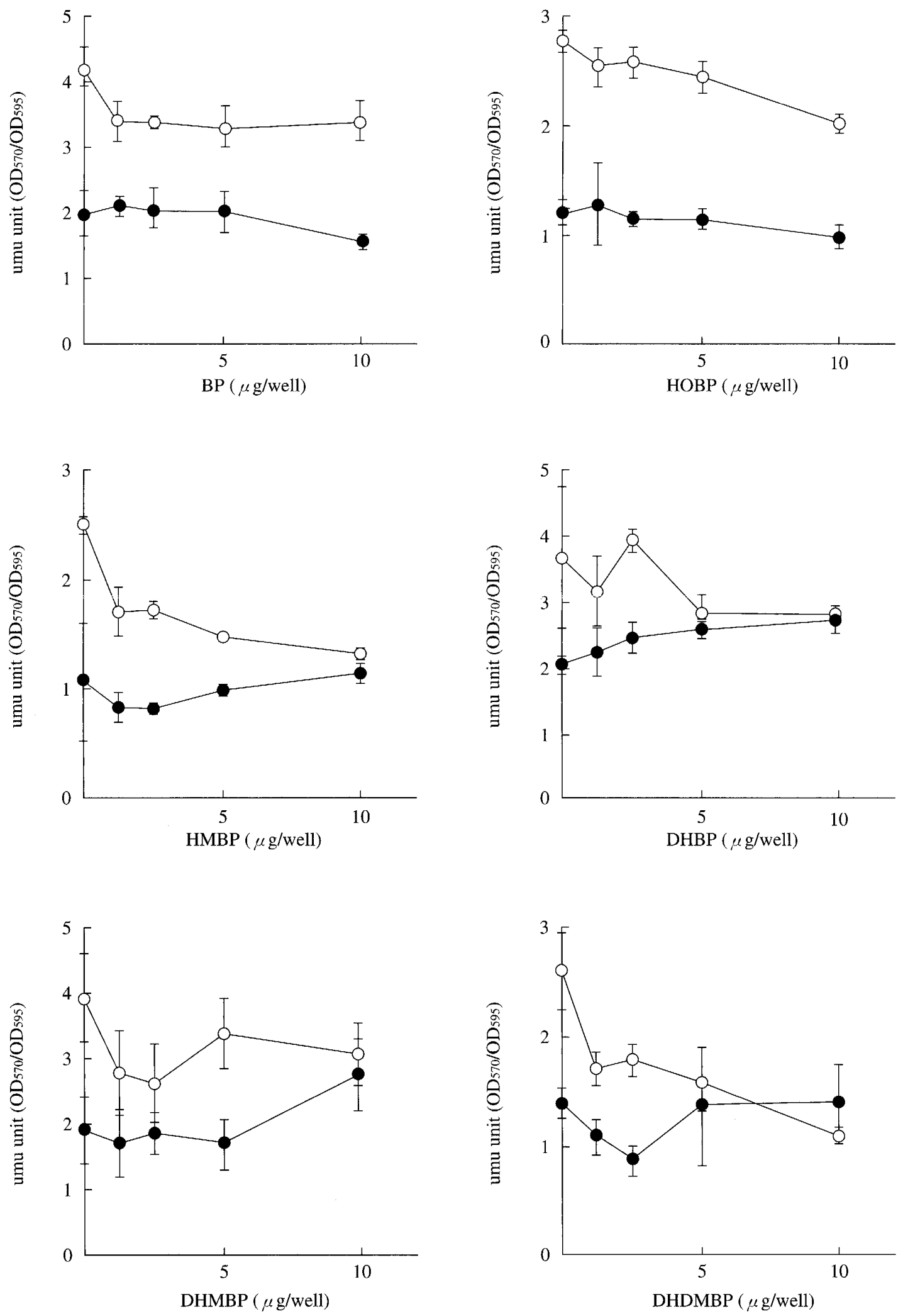

Fig. 2. Results of the light absorption $u m u$-test of benzophenones.

$$
\bigcirc \text { : Diluted with DMSO, : Diluted with methanol. }
$$



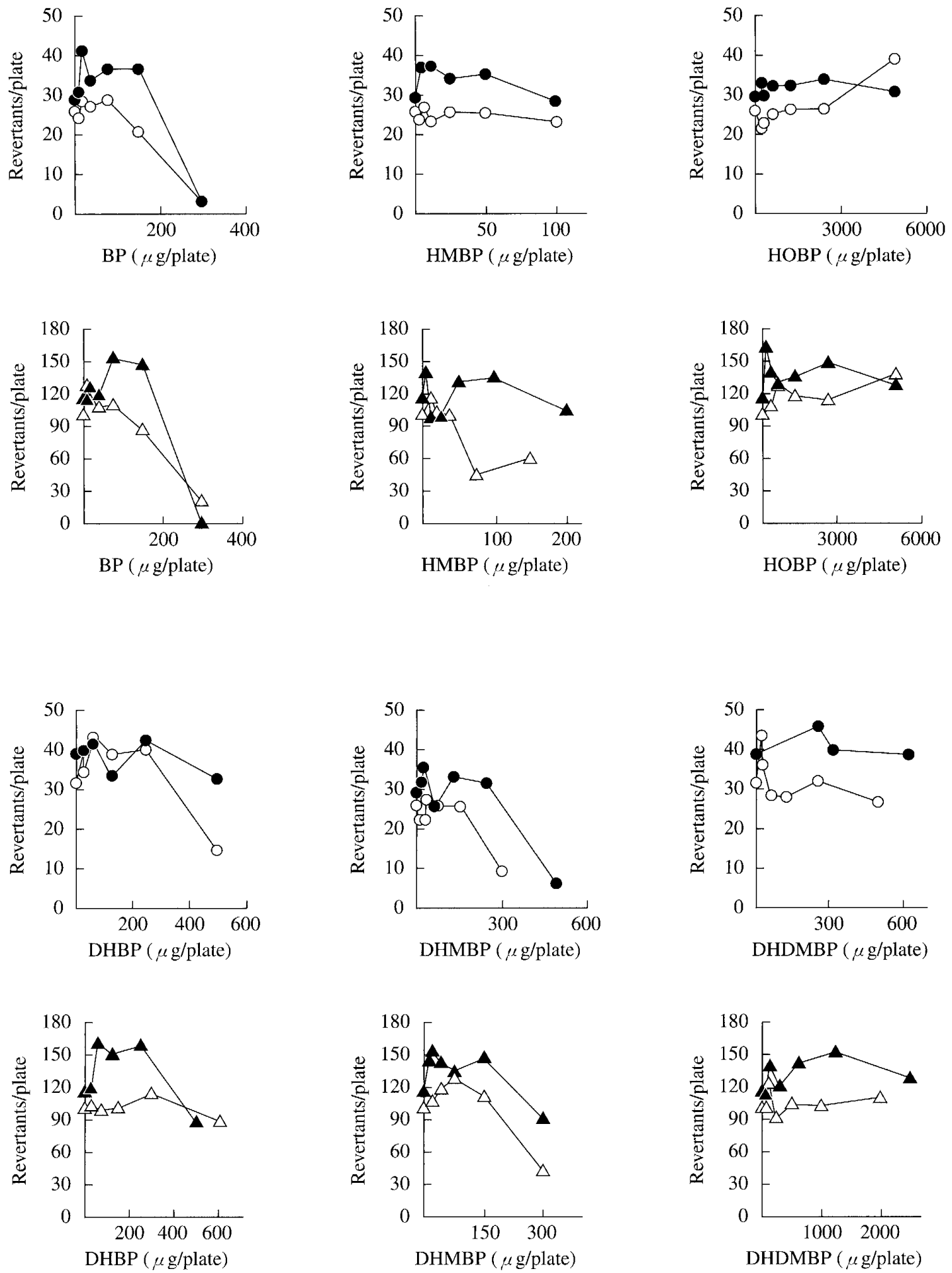

Fig. 3. Results of the Ames test of benzophenones.

$$
\bigcirc: \text { TA98 - S9, : TA } 98+S 9, \triangle: \text { TA } 100-S 9, \Delta: \text { TA } 100+S 9 .
$$




\section{The Ames test for initiation activity}

Next, we tested for mutagenicity, one of the initiation activities (Fig. 3). There are two internationally prevailing methods for the Ames test: the plate method developed by Dr. B. Ames [13], and the pre-incubation method, which has enhanced the sensitivity of the plate method [14]. The tests in this study used TA98 strain for easier detection of frame-shift mutations, and TA100 strain for detection of base substitution mutations. In addition, the tests for the $+\mathrm{S} 9$ mix condition were performed at the same time that the Ames metabolic activation test was established, whereas neither the luminescent nor light absorption $и т и$-tests was performed as a test for metabolic activation by the S9 mix. HOBP produced 1.5 times as many revertant colonies as the solvent controls at a concentration of $5 \mathrm{mg} / \mathrm{plate}$ under the non-metabolic activity conditions of strain TA98, but not 2 times as many, therefore resulting in a pseudo-positive. Because the five other benzophenones showed inhibition of bacterial growth at each of the concentration levels or higher, the results shown were obtained by dilution adlibitum. None of the compounds produced clear positive results under any condition, and the mutagenicity was negative.

\section{Bhas assay for carcinogenic promotion}

Table 2 shows the results of the Bhas assay for carcinogenic promotion. It should be noted that the highest or the second highest concentration level for each of the tested benzophenones was set, based on the results of a previous dosage test, at a level at which the survival rate of the cultured cells was between 50 and $70 \%$. Treatment with BP, HMBP, HOBP or DHDMBP did not result in any significant increase in the number of foci relative to the solvent controls at any concentration level, indicating negative promotion activity. $\mathrm{BP}, \mathrm{DHMBP}$ and DHDMBP in particular produced less foci than the solvent controls at 100 $\mu \mathrm{g} / \mathrm{ml}, 20 \mu \mathrm{g} / \mathrm{ml}$ and above $5 \mu \mathrm{g} / \mathrm{ml}$, respectively. The cell survival rates declined in all compounds at the concentration level at which the number of foci decreased. As a result, the effect of cytotoxicity was believed to be the cause of the decrease in the number of foci. A microscopic examination showed cells of a flattened round shape in the DHDMBP test group.

In the DHBP group, there was no increase in the number of foci at concentrations below $5 \mu \mathrm{g} / \mathrm{ml}$. At $10 \mu \mathrm{g} / \mathrm{ml}$, however, there was a significant increase to $6.0 \pm 2.4 \mathrm{foci} /$ well, which was more than twice that of the number of foci in the solvent controls $(2.2 \pm 1.5 \mathrm{foci} /$ well). However, the increase was $1.5 \%$ per gram when compared to the number of foci in the positive controls $(50 \mathrm{ng} / \mathrm{ml}$ TPA, $20.2 \pm 5.2 \mathrm{foci} /$ well). At the highest concentration of $20 \mu \mathrm{g} / \mathrm{ml}$, the number of foci was comparable to that of the solvent controls, but the cell survival rate was lower $(31 \%)$, suggesting the toxicity of the test substance. Based on the above results, which satisfied one of the positive response criteria of "a significant increase to more than twice that of the controls," 2,4-dihydroxybenzophenone was believed to be a tumor promoter. Its potential, however, was apparently weak in comparison to the level in 
Table 2. Tumor promoting potential of benzophenones

\begin{tabular}{|c|c|c|c|c|c|c|}
\hline \multirow{3}{*}{$\begin{array}{l}\text { Concentration } \\
\qquad(\mu \mathrm{g} / \mathrm{ml})\end{array}$} & \multicolumn{6}{|c|}{ Tumor-promoting potential (foci/well) } \\
\hline & $\mathrm{BP}$ & HOBP & HMBP & DHBP & DHMBP & DHDMBP \\
\hline & \multicolumn{6}{|c|}{$($ mean $\pm \mathrm{SD})$} \\
\hline 0 & $2.2 \pm 1.5$ & $2.5 \pm 1.5$ & $2.2 \pm 1.5$ & $2.2 \pm 1.5$ & $2.5 \pm 1.9$ & $2.5 \pm 1.9$ \\
\hline 0.2 & & $2.0 \pm 1.7$ & $1.2 \pm 0.8$ & & & $2.8 \pm 0.8$ \\
\hline 0.5 & & $1.8 \pm 1.2$ & $2.5 \pm 1.4$ & $2.0 \pm 1.3$ & $3.7 \pm 2.1$ & $2.2 \pm 2.1$ \\
\hline 1 & & $3.2 \pm 1.2$ & $2.2 \pm 0.8$ & $2.0 \pm 2.2$ & $2.7 \pm 2.4$ & $2.0 \pm 1.1$ \\
\hline 2 & $1.7 \pm 1.4$ & $2.8 \pm 1.8$ & $3.2 \pm 1.5$ & $2.3 \pm 1.0$ & $2.0 \pm 1.4$ & $1.7 \pm 1.2$ \\
\hline 5 & $2.6 \pm 1.4$ & $2.5 \pm 1.2$ & $2.8 \pm 1.7$ & $2.7 \pm 1.5$ & $1.7 \pm 1.5$ & $0.0 \pm 0.0$ \\
\hline 10 & $2.6 \pm 1.4$ & $3.7 \pm 1.0$ & $3.7 \pm 2.0$ & $6.0 \pm 2.4^{*}$ & $1.7 \pm 2.9$ & $0.0 \pm 0.0$ \\
\hline 20 & $3.1 \pm 1.2$ & & & $2.7 \pm 1.5$ & $0.8 \pm 0.8$ & \\
\hline \multicolumn{7}{|l|}{50} \\
\hline 100 & $0.5 \pm 0.5$ & & & & & \\
\hline TPA $(50 \mathrm{ng} / \mathrm{ml})$ & $20.1 \pm 5.1$ & $21.5 \pm 3.5$ & $20.1 \pm 5.1$ & $20.1 \pm 5.1$ & $21.2 \pm 3.5$ & $21.2 \pm 3.5$ \\
\hline \multirow{2}{*}{$\begin{array}{l}\text { Concentration } \\
\qquad(\mu \mathrm{g} / \mathrm{ml})\end{array}$} & \multicolumn{6}{|c|}{ Cell viability ( $\%$ of control) } \\
\hline & $\mathrm{BP}$ & HOBP & HMBP & DHBP & DHMBP & DHDMBP \\
\hline 0 & 100 & 100 & 100 & 100 & 100 & 100 \\
\hline 0.2 & & 88.6 & 104.5 & & & 98.8 \\
\hline 0.5 & & 97.4 & 106.7 & 103.2 & 91.1 & 112.4 \\
\hline 1 & & 89.4 & 96.6 & 102.4 & 98.3 & 111.9 \\
\hline 2 & 84.8 & 108.7 & 97.9 & 95.3 & 84.3 & 99.6 \\
\hline 5 & 91.4 & 96.4 & 78.5 & 92.8 & 82.3 & 64.6 \\
\hline 10 & 111.6 & 90.2 & 55.9 & 67.4 & 70.8 & 43.5 \\
\hline 20 & 82.9 & & & 30.7 & 45.5 & \\
\hline \multicolumn{7}{|l|}{50} \\
\hline 100 & 29.3 & & & & & \\
\hline TPA $(50 \mathrm{ng} / \mathrm{ml})$ & -** & - & - & - & - & - \\
\hline
\end{tabular}

the positive controls.

As the above test results show, four out of the six types of benzophenones used in our study (i.e. HMBP, DHBP, HOBP and DHMBP) produced positive or pseudo-positive initiation activity in either the umu-tests or the Ames test. DHBP in particular showed both initiation and promotion activities. Although these activities were weak in all compounds tested, because they exist in common plastic products, we may still be exposed to them for long periods even if at low concentration levels. Further studies are needed to determine the presence, exposure and level of effect that these substances have in the environment.

\section{Acknowledgement}

The authors are grateful to researchers at Toyota Central R \& D Laboratories for supply- 
ing S. typhimurium TL210. This work was supported in part by a grant-in-aid from the Ministry of the Environment, Japan.

\section{References}

1. Ohte Y (1998): Shigaisen Kyushuzai ultraviolet absorbers (UVA), Kobunshi Tenkazai no Shintenkai. Chemical Society of Japan and the Society of Polymer Science, ed. Japan: Nikkan Kogyosha, Tokyo $56 \mathrm{pp}$

2. Wang S-P \& Lee W-T (2003): Determination of benzophenones in a cosmetic matrix by supercritical fluid extraction and capillary electrophoresis. J Chromatogr A 987:269-275

3. The Ministry of Environment (2000): MOE's Perspectives on Endocrine Disrupting Effects of Substances - Strategic Program on Environmental Endocrine Disrupters. SPEED '98 http://www.env. go.jp/chemi/end/endindex.html

4. Suzuki T, Kitamura S, Khota R, Sugihara K, Fujimoto N \& Ohta S (2005): Estrogenic and antiandrogenic activities of 17 benzophenone derivatives used as UV stabilizers and sunscreens. Toxicol Appl Pharm 203: 9-17

5. Benfenati E, Toro ND, Fanelli R, Lualdi G, Tridico R, Stella G, Buscaini P \& Stimilli L (1992): Characterization of organic and inorganic pollutants in the Adige river (Italy). Chemosphere 25: 1665-1674

6. Ricking M, Schwarzbauer J \& Franke S (2003): Molecular markers of anthropogenic activity in sediments of the Havel and Spree Rivers (Germany). Water Res 37: 2607-2617

7. Robinson SH, Odio MR, Thompson ED, Aardema MJ \& Kraus AL (1994): Assessment of the in vivo genotoxicity of 2-hydroxy-4-methoxybenzophenone. Environ Mol Mutagen 23: 312-317

8. Koschier FJ, Naismith RW, Godek E \& Friedman MA (1982): Mutagenicity testing of 2,2'dihydroxy-4-methoxybenzophenone (benzophenone-8, UV-24). Environ Mutagen 4:340

9. Sugimura T (1992): Multistep carcinogenesis: a 1992 perspective. Science 259: 603-607

10. Oda Y, Nakamura S, Oki I, Nakata A \& Shinagawa H (1984): Short-term environmental mutagen detection method (umu-test) using umu-lac fusion gene. Environ Mutagen Society $\quad 6: 87-92$

11. Goto S, Kato Y, Endo O, Yamaguchi T \& Matsushita H (1988): A highly sensitive $u m u$-test by fluorometric method. J Japan Soc Air Pollut 23: 123-127

12. Tanada K, Goto S, Kadokami K, Hirai M, Imaeda T \& Suzuki M (2001): Modification of umu-test using the bioluminescent bacteria and application to sediments and soils. J Environ Chem 11: $841-848$

13. Maron DM \& Ames BN (1983): Revised methods for Salmonella mutagenicity test. Mutat Res 113: $173-215$

14. Yahagi T, Nagao M, Seino Y, Matsushima T, Sugimura T \& Okada M (1977): Mutagenicities of Nnitrosoamines on Salmonella. Mutat Res 48:121-130

15. Ohmori K, Miyazaki M \& Umeda M (1998): Detection of tumor promoters by early antigen expression of EB virus in Raji cells using a fluorescence microplate-reader. Cancer Lett 132: 51-59

16. Sasaki K (1992): Screening system of promoters using ras transfected BALB 3 T3 clone (Bhas 42). Invitrotox Protocol 62: 1-11

17. Sakai A, Iwase Y, Nakamura Y, Sasaki K, Tanaka N \& Umeda M (2002): Use of a cell transformation assay with established cell lines, and metabolic cooperation assay with V79 cells for the detection of tumor promoters: a review. ATLA 30:33-59

18. Ohmori K, Sasaki K, Asada S, Tanaka N \& Umeda M (2004): An assay method for the prediction of tumor promoting potential of chemicals by the use of Bhas 42 cells. Mutat Res 557: 191-202 
19. Goto S, Asada S, Fushiwaki Y, Mori Y, Tanaka N, Umeda M, Nakajima D \& Takeda K (2004): Tumor-promoting activity and mutagenicity of 5 termiticide compounds. J UOEH 26: 423-430

20. Ezoe Y, Ohkubo T, Ohmori K, Fushiwaki Y, Mori Y, Umeda M \& Goto S (2004): Promoter and mutagenic activity of particulate matter collected from urban air. J Health Sci 50: 181-184

21. Martinez A, Urios A \& Blanco M (2000): Mutagenicity of 80 chemicals in Escherichia coli tester strains IC203, deficient in OxyR, and its $o x y R^{+}$parent WP2 $u v r A / p K M 101$ : detection of 31 oxidative mutagens. Mutat Res 467: 41-53

22. Stenbäck F \& Shubik P (1974): Lack of toxicity and carcinogenicity of some commonly used cutaneous agents. Toxicol Appl Pharm 30:7-13

23. Cosmetic Ingredient Review (1983): Addendum to the final report on the safety assessment of benzophenone 1, 3, 4, 5, 9 and 11 to include benzophenone 2, 6, 8. J Amer Col Toxicol 2: $79-84$

24. Cosmetic Ingredient Review (1983): Final report on the safety assessment of benzophenones-1, -3, -4, -5, -9 and -11. J Amer Col Toxicol 2:35-77

25. Popkin DJ \& Prival MJ (1985): Effects of $\mathrm{pH}$ on weak and positive control mutagens in the Ames Salmonella plate assay. Mutat Res 142: 109-113

26. Kanai H, Barrett JC, Metzler M \& Tsutsui T (2001): Cell-transforming activity and estrogenicity of bisphenol-A and 4 of analogs in mammalian cells. Int J Cancer 93: 20-25

27. Nakajima D, Ishii R, Nishimura K, Takagi Y, Mineki S, Onodera S \& Goto S (2005): Effects of organic solvent in luminescent $u m u$-test using S. typhimurium TL210. J Environ Chem 15: 569574

28. Nakamura S, Oda Y, Shimada T, Oki I \& Sugimoto K (1987): SOS-inducing activity of chemical carcinogens and mutagens in Salmonella typhimurium TA1535/pSK1002: examination with 151 chemicals. Mutat Res 192:239-246 
ベンゾフェノン系プラスチック添加剤の発がん関連活性

中島 大介 ${ }^{\prime}$, 浅田 晋 ${ }^{2}$, 影山 志保 ${ }^{1}$, 山本 貴士 ${ }^{3}$, 倉持 秀敏 ${ }^{3}$,

田中 憲穂 ${ }^{2}$, 武田健 ${ }^{4}$, 後藤 純雄 ${ }^{1}$

1独立行政法人 国立環境研究所 環境リスク研究センター

2 (財) 食品薬品安全セン夕ー 秦野研究所

3独立行政法人 国立環境研究所 循環型社会・廃棄物研究センター

4 東京理科大学 薬学部

要 旨： 紫外線吸収剂としてプラスチックに添加されているベンゾフェノン誘導体のうち 6 種 類(ベンゾフェノン,2-ヒドロキシ-4-オクチルオキシベンゾフェノン,2-ヒドロキシ4-メトキシベンゾフェノン,2,4-ジヒドロキシベンゾフェノン 2,2 - -ジヒドロキシ-4メトキシベンゾフェノン抢よび2,2'-ジヒドロキシ-4,4'-ジメトキシベンゾフェノ ン)について,発がん関連活性を調べた.イニシエーション活性は, 吸光 $u m u$ 試験, 発光 umu 試験抢よびAmes 試験を用いて評価した.プロモーター活性は, Bhas42 細胞を使 用する形質転換フォーカス形成試験法である Bhas assayを用いて検討した. その結果， イニシエーション活性では発光 $u m u$ 試験から 2-ヒドロキシー4-メトキシベンゾフャ， ンが陽性と認められ, 2,4-ジヒドロキシベンゾフェノンおよび 2,2 - -ジヒドロキシ-4メトキシベンゾフェノンは擬陽性と認められた.また, Ames 試験ではHOBPが擬陽性 を示した。一方 2,4 -ジヒドロキシベンゾフェノンについては, $10 \mu \mathrm{g} / \mathrm{ml}$ に扔いて弱い プロモーション活性が認められた。

キーワード： 発光 $u m u$ 試験，吸光 $u m u$ 試験，エームス試験，Bhas プロモーション試験，2,4-ジヒ ドロキシベンゾフェノン。

J UOEH（産業医大誌）28（2）：143-156（2006） 